\title{
SHF and Grenoble: La Houille Blanche, Beauvert Laboratory and Men
}

\author{
Willi H. Hager ${ }^{1}$
}

I.Em.Prof., VAW, ETH Zurich, CH-8093 Zürich, Switzerland.E-mail: hager@vaw.baug.ethz.ch

\begin{abstract}
The Hydrotechnical Society of France was founded in 1912. Its purpose was to adequately represent the interests of the French hydropower industry. The SHF history from its creation to World War II is described, including the Beauvert Hydraulic Laboratory at Grenoble with its main projects and its actors, the journal La Houille Blanche, and its difficult years in the 1930s. It is thus intended to look back into the era of the glorious French advances in hydraulic engineering, but also to the re-creation after WWII.
\end{abstract}

Key-words: Beauvert Hydraulic Laboratory, Biography, history of hydraulics, roughness, Société Hydrotechnique de France, uniform flow.

\section{La SHF et Grenoble : La Houille Blanche, le laboratoire de Beauvert et les hommes}

\begin{abstract}
RESUME. - La Société Hydrotechnique de France a été fondée en 1912. Son but était de représenter les intérêts de l'industrie d'hydro-électricité française. L'histoire de la SHF, de sa création à la deuxième Guerre mondiale est décrite ici, y compris celle du Laboratoire Hydraulique de Beauvert à Grenoble avec ses projets principaux et ses acteurs, du journal La Houille Blanche et de ses années difficiles dans les années 1930. Il est ainsi destiné à un regard vers le passé à l'ère des glorieuses avancées françaises dans l'ingénierie hydraulique, mais aussi à sa reconstitution après la Seconde Guerre mondiale.
\end{abstract}

Mots-clés : Laboratoire Hydraulique de Beauvert, Biographie, histoire de l'hydraulique, rugosité, Société Hydrotechnique de France, écoulement uniforme.

\section{INTRODUCTION}

Société Hydrotechnique de France (SHF) was founded in 1912 mainly by industrialists interested in the development and the use of hydropower. The idea had come already during the first Congress of La Houille Blanche (The White Coal, a French expression for hydropower), held at Grenoble in 1902. It lasted a week including a trip to near Switzerland. As typical in this era, no less than 15 honorary presidents were elected, with Charles Pinat (1854-1905) as Congress President. More than 600 participants were counted. There was of course space for a banquet at the Grande Salle de l'Orangerie, Grenoble. The congress included the topics climatology, hydrology, hydrometry, intake structures, dam design, water resources, turbine tests, electricity aspects of hydropower generation, and law aspects. Volume 1 gives an account of these items, including the papers presented, whereas volume 2 highlights the then main hydropower installations both in the French and the Swiss-French Alps. Regretfully, the Congress actors are not presented. An important result of this Congress was the foundation of the journal La Houille Blanche, however, defined as a general journal for hydropower engineering and its applications. Its first series lasted until 1939, whereas the second series continued in 1945.

The second SHF-Congress was held at Lyon in 1914 shortly after WWI had started. The president of the Technical Section was Augustin Blanchet, an industrial engineer of Rives. An important paper deals with the Venturi meter for accurate discharge measurement authored by Charles
Camichel, Denis Eydoux, and J. Lhériaud (Camichel et al. 1914). It was concluded that this hydraulic meter counts to the most accurate and simplest available, and therefore was recommended for use in the hydropower industry. A similar paper was presented by Rateau (1914). Jouguet (1914) read

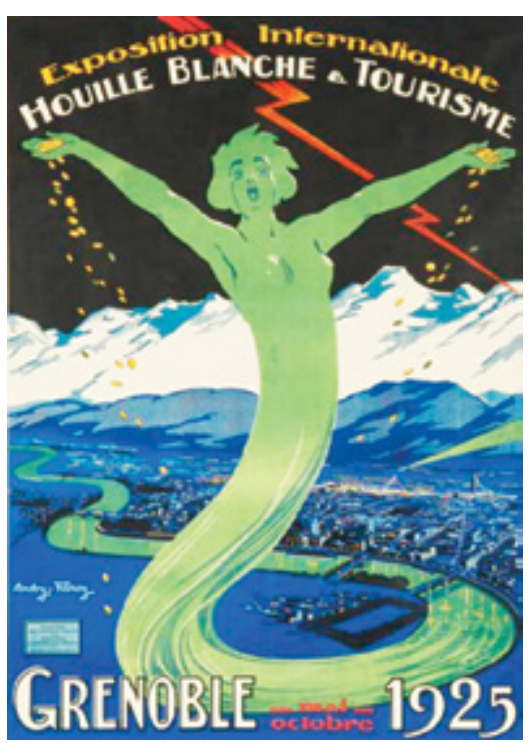

Figure 1 : Image of inspiration of the 1925 Grenoble Congress Hydropower and Tourism (http://fr.wikipedia.org/ wiki/Exposition internationale de la houille blanche) 
a paper on water hammer, its mathematical formulation and the integration of the governing differential equations, both for incompressible and compressible fluids. For the latter, the approach of the Italian Lorenzo Allievi (1856-1940) was generalized and typical cases of the hydropower industries were considered. Then recent laboratory tests of water hammer in air conduits were compared with the computational approach by de Sparre (1914). Other papers dealt with the design and construction of large concrete or metal conduits, of recent turbines, and of high-tension electric lines.

The third and last SHF-Congress before WWII was held at Grenoble in 1925 (Fig. 1). For a Swiss, the number of greeting talks and papers dealing with economical and legal hydropower aspects is overwhelming, in contrast to the modest number of technical papers. Volume 2 includes a paper on SHF and the Beauvert Laboratory, to be discussed below. The last 300 pages are devoted to novel hydropower installations of SHF members. Note that these congresses count to the very early, setting standards for these to come in the 1930 s, e.g. the International Committee of Large Dams (ICOLD) or the International Association of Hydraulic Research (IAHR).

\section{FRENCH HYDRAULIC LABORATORIES IN THE 1930s}

Jaeger (1937) describes the operational hydraulic laboratories of France:

- Beauvert directed by R. Bourgeat, with a particular interest in pipe flows, orifice and Venturi meters, and velocity distribution in converging pipes;

- Hydraulic laboratory of Toulouse University founded in 1913 and since directed by Prof. C. Camichel. His colleagues Profs. Eydoux, Foch and Escande supported him in all research activities. The laboratory was also under SHF supervision. Of particular interest were water hammer tests and computation, hydraulic similitude, and vortex flow. Scale effects in hydraulic modelling using scale families were also explored;

- Hydraulic laboratory of Grenoble Polytechnic Institute founded in 1929, of which only one room was completed by 1935, however. The research activities included turbine and pump flows;

- Experiment Institute of Nancy University, founded in 1903 and from the 1930s directed by Prof. E. Hahn (Hahn and Hager 2003), with turbine and pump tests, along with head-losses across racks, and flow features of weirs. Few papers were published;

- Experiment Station at Saulcy, Metz, founded in 1929 as a SHF unit, with particular research interest in open channel flow, mainly the compound flow features. This was essentially an open-air facility; and

- Hydraulic Laboratory of Châlons sur Saône, directed by Prof. Tenot. He took interest in turbine and pump tests, and questions of hydraulic similitude. In addition, cavitation experiments were conducted.

- The paper ends with a summary of the most relevant publications on these laboratories. Noteworthy, the Author was unable to find indications on the Beauvert Laboratory after WWII, but noticed that this facility was no more listed by Anonymous (1950). Anonymous (1957) only mentions five active French hydraulic laboratories, namely SOGREAH at Grenoble, Chatou associated with Electricité de France (EDF), laboratory at Maisons-Alfort, and two small units at the Universities of Toulouse and Grenoble.

\section{BEAUVERT HYDRAULIC LABORATORY}

\section{III.1. Installations}

Given that SHF mainly dealt with turbines and hydropower, its members were and still are practice-oriented, with a view on the rich French hydraulics school founded in the $18^{\text {th }}$ century. It is not particularly involved in educational programs, but corporates with the Universities of Grenoble, Nancy, and Toulouse. The initiation of works was interrupted by WWI, so that only in 1920 the decision was taken to erect the Laboratory. Until 1923 few projects were completed, namely (Freeman 1929, Anonymous 1925):

- Venturi meter for discharge measurement in large conduits;

- Water hammer and its verification by laboratory data;

- Surge tank and its optimum performance in hydropower facilities;

- Maps showing the distribution of French electric power production; and

- Progress reports for SHF members.

Beauvert Lab (Fig. 2) should mainly deal with turbine regulation, whereas the Nancy Laboratory rather should investigate optimum blade shapes of turbines. The Beauvert Laboratory included the following units:

- Hydraulic machinery;

- Two rectangular channels to study free surface flow; and

- Piping systems to investigate head losses.

The Turbine Laboratory was $35 \mathrm{~m}$ long, $16 \mathrm{~m}$ high, and $16 \mathrm{~m}$ wide, allowing for turbine tests under heads ranging from $2 \mathrm{~m}$ to $200 \mathrm{~m}$. For low-head tests both turbines with horizontal or vertical axes were considered. Discharges up to $2,350 \mathrm{l} / \mathrm{s}$ were run, with the discharge measurement made by Bazin weirs, and a special gate. The medium-head turbines were tested up to $750 \mathrm{l} / \mathrm{s}$ and heads up to $9 \mathrm{~m}$. The power output was measured with a Prony Brake. High-head turbine tests allowed for a maximum discharge of $15 \mathrm{l} / \mathrm{s}$; an air chamber with a safety apparatus was inserted between the pump and the turbine. The Laboratory is shown in Fig. 3. It
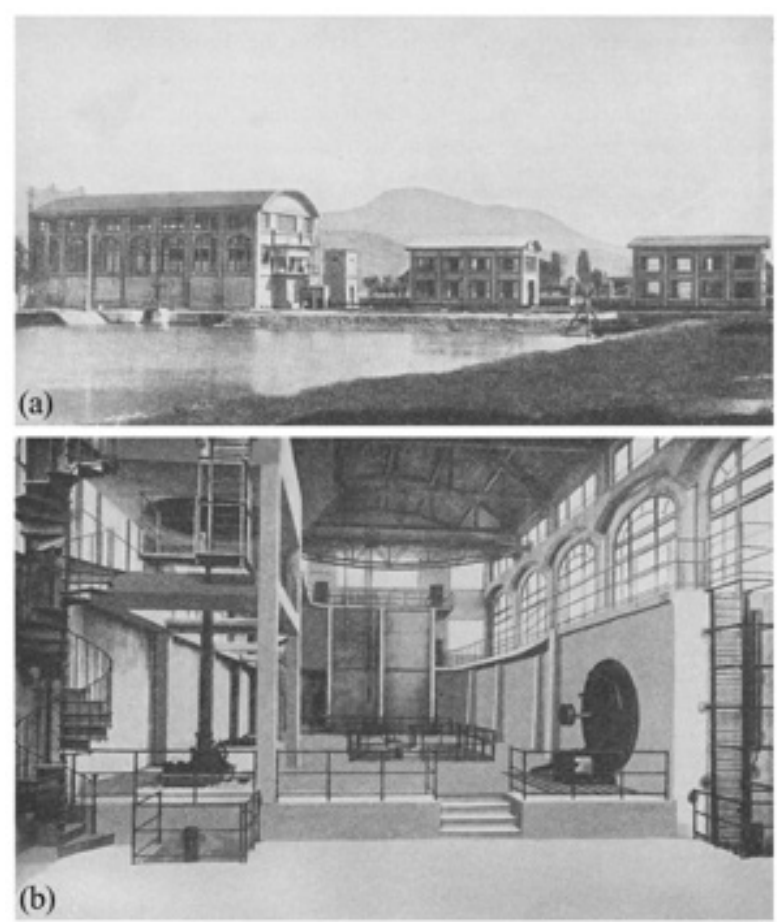

Figure 2 : Beauvert Hydraulic Laboratory (a) outdoor, (b) indoor view (Freeman 1929) 


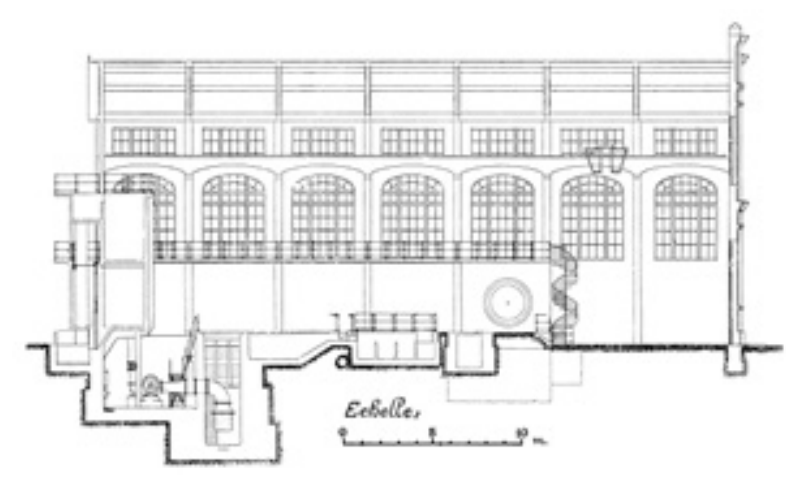

Figure 3 : Beauvert Hydraulic Laboratory, longitudinal section (Anonymous 1935)

included a crane serving model stands all along the test sites with a lift capacity of $4 \mathrm{t}$.

The open channel flow sites were used both as tailrace canals of turbine stands, and for independent research dealing with head losses, e.g. across screens or past obstacles. They were also used to study wave features due to sudden turbine opening or closing scenarios. Figure 4 shows views at one of the channels and its end with the weirs for discharge tests.

The piping system site was connected with a pump of $400 \mathrm{l} / \mathrm{s}$ discharge capacity feeding a $60 \mathrm{~m}$ long system along which various set-ups were tested, including elbows, branches or nozzles, as typically employed in the hydropower industry. A second facility included a surge tank to measure the head losses following unsteady discharge scenarios.

The Beauvert Laboratory included in addition a workshop, a machine shop, and an office house. An annex building (Diderot Annex) located at the Electro-technical Institute of Grenoble University was used to study the flow over weirs and dams, and to calibrate current meters (Fig. 5).
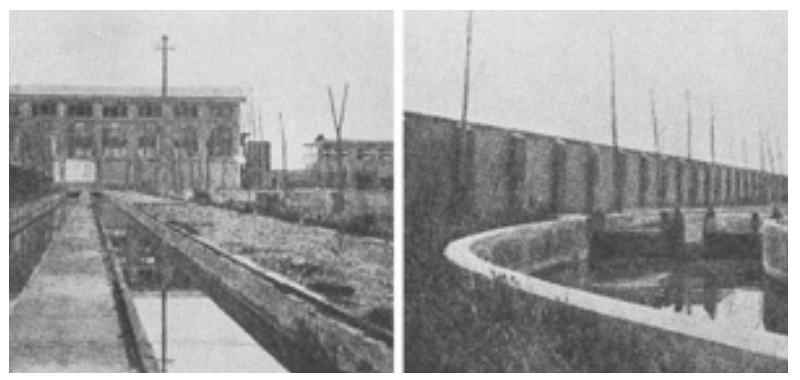

Figure 4 : Experiment channel (a) test reach, (b) discharge measurement at channel end (Freeman 1929)

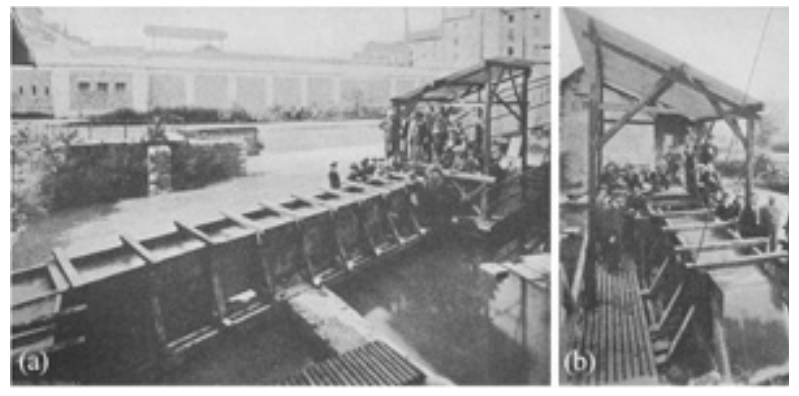

Figure 5 : Diderot Annex, hydraulic tests on (a) current meters, (b) weirs (Freeman 1929)
Further descriptions on the Beauvert Laboratory were given by Routin (1912) with a particular view on the Diderot Annex, Barbillion (1916), Anonymous (1922) presenting the principal hydraulic engineers, namely Georges Routin (1871-1937) and his collaborator R. Bourgeat, Anonymous (1924), and Anonymous (1928), in which the set-ups are presented, yet no results given. Maurin (1921) lists all by then active laboratories of France.

\section{III.2. Experimental results}

Leroux (1931) highlights the projects of Beauvert Laboratory until 1930:

- Pipe experiments of various internal roughness patterns;

- Smooth pipe tests; and

- Verification of temperature and viscous effects of Reynolds' pipe law.

These experiments demonstrated the advantages of smooth over rough pipes, by which the typical head loss is reduced to $75 \%$. A dimensionally wrong pipe flow formula was also proposed.

Further tests related to orifice meters to determine pipe discharge. The problem involved a known head on the meter, and its geometrical shape, for which the resulting coefficient of discharge $m$ was determined. Large orifice dimensions were selected to increase accuracy. A funnel type A, and an elliptically-shaped type B orifice geometry were selected, with orifice diameters from $D=10$ to $80 \mathrm{~mm}$ (Fig. 6). The data were plotted as $m(\mathrm{R})$, with $\mathrm{R}=U D / v$ as Reynolds number, and $v$ as the kinematic fluid viscosity. These plots indicate that $D=10 \mathrm{~mm}$ deviates from the remainder because of scale effects, whereas the others slightly differ if $R<7 \pm 10^{4}$. For larger $\mathrm{R}$, the effect of $D$ is negligible, resulting in $m=0.985 \pm 0.005$. Scale effects were thus detected, which were accepted for practical purposes, however.
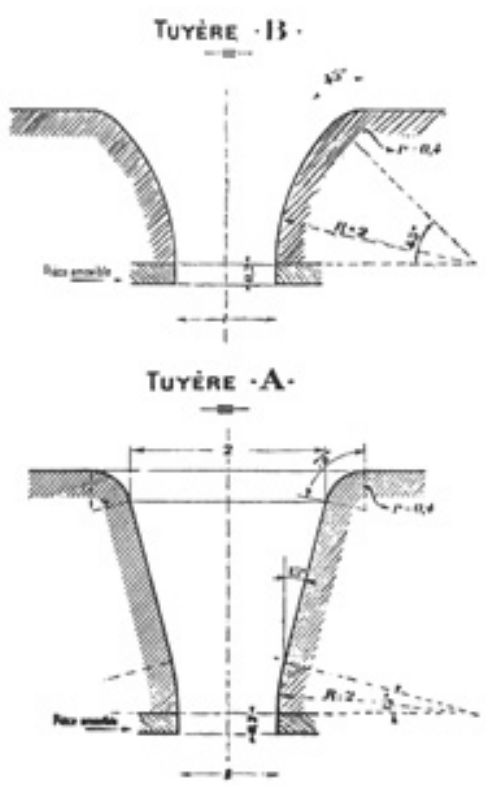

Figure 6 : Orifice meter types $A$ and B (Anonymous 1935)

Leroux (1932a) adds to the previous description the following results:

- River experiments;

- Pressure distribution on Stoney gates;

- Scour tests; and

- Collaboration with Saulcy Laboratory. 
Tests in a $100 \mathrm{~m}$ long, and $2 \mathrm{~m}$ wide glazed channel were conducted, of which the right side was replaced over $10 \mathrm{~m}$ by five panes of glass $20 \mathrm{~mm}$ thick, behind which a trench was excavated to accommodate the test observers. Stoney gates were installed to determine the pressure distribution, allowing for the optimum gate shape for minimum efforts to lift the gate. The best solution was then adopted in hydropower practice.

The weir and the tailwater tunnel of Chambon Dam on Romanche River were also tested. The model scale was 1:12. As shown in Fig. 7, the weir is arranged along a bend, generating vortical flow in the so-called side-channel, which is directed toward the tunnel. The limit discharge for tunnel priming was of particular interest; the tunnel intake geometry was then improved by funneling, and a second test
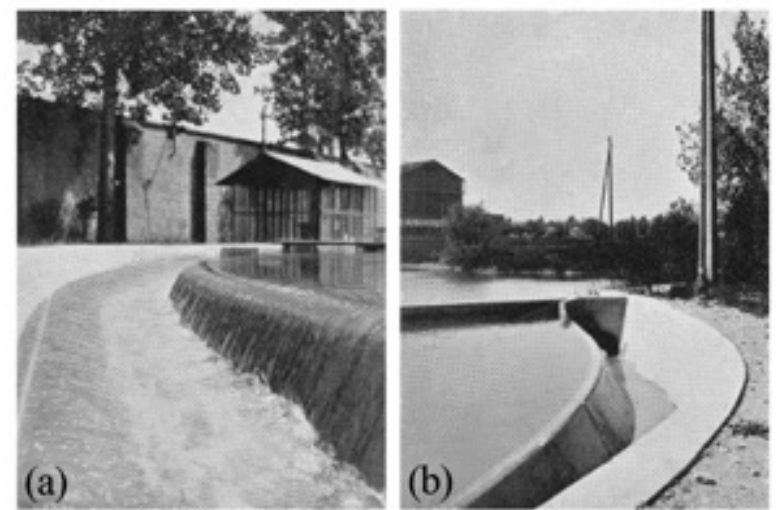

Figure 7 : Chambon Dam tests (a) side-channel, (b) tunnel intake (Leroux (1932a)

indicated improvement of the flow along with a discharge capacity of $350 \mathrm{~m}^{3} / \mathrm{s}$.

A large test campaign was devoted to Kembs weir on the Rhine River. A particular question related to the optimum intake arrangement to the Grand Canal d'Alsace. The model had a scale of 1:200. Figure 8 a shows velocity measurements using threads attached to a transverse support, resulting in the velocity directions. The absolute velocity was read with ballasted floats in their passage between two reference sections. The project also included early measurements of scour at weir vicinity (Fig. 8b). Most of these techniques had by then been developed at the specific hydraulic laboratory. It was stated that France profited of these facilities by which

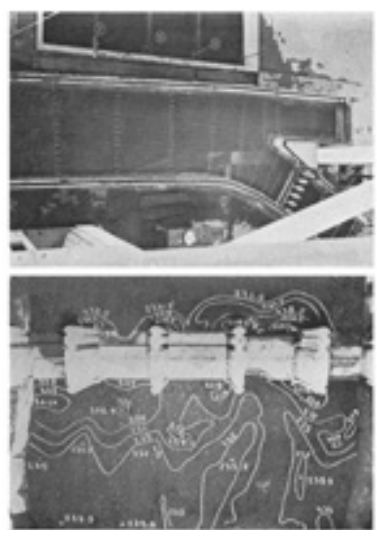

Figure 8 : Kembs weir on Grand Canal d'Alsace (a) approach flow, (b) tailwater scour (Leroux 1931) the practical and scientific advance in hydraulic engineering was guaranteed. A review of the above and additional results is provided by Leroux (1932b).

After Leroux's death, few publications were written, given that successor Bourgeat had no academic background; he was interested in daily projects but no fundamental research. Nizéry (1948), then director of the Hydraulic Laboratory at Chatou, founded in 1930 also under the supervision of SHF, states: 'From the evolution of hydraulic modelling, particularly the systematic use of scale models in hydraulic engineering, the equipment of the Beauvert Laboratory was less and less adapted for its role; along with a reduced but excellent personnel, this laboratory declined.'

The last account of Beauvert Laboratory gives Anonymous (1935). Figure 9 shows the installation by which velocity meters were calibrated in still water by trailing it with a

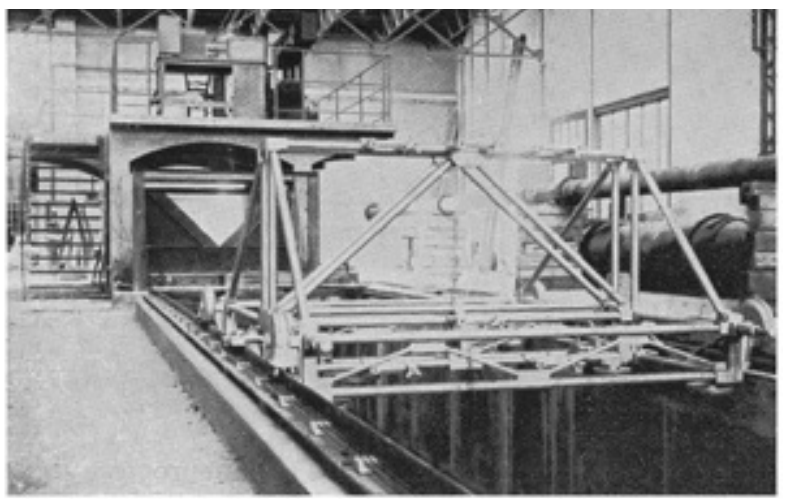

(a)

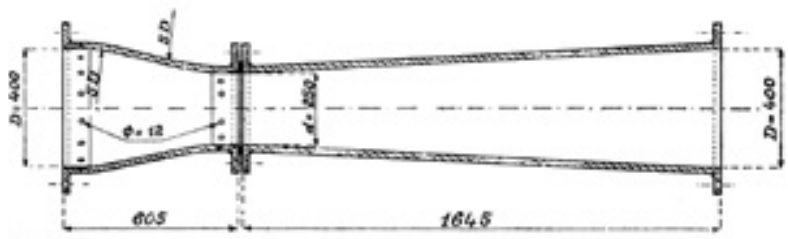

(b)

Figure 9 : Calibration set-up for (a) velocity meters, (b) Venturi meters at Beauvert Lab (Anonymous 1935)

known speed, an approach widely applied in hydraulic laboratories. At Beauvert, the test canal was $2 \mathrm{~m}$ wide and $100 \mathrm{~m}$ long allowing for $6 \mathrm{~m} / \mathrm{s}$ maximum speed. A special calibration unit enabled the simultaneous test of various instruments.

Another research program executed at Beauvert involved Venturi meters, i.e. locally contracting pipe elements causing an increase of velocity and a simultaneous decrease of pressure at the contracted section. Figure $9 \mathrm{~b}$ shows a typical set-up involving a short, S-shaped confusor, followed by a linearly expanding diffusor. The approach flow diameters selected were $D=200,300$, and $400 \mathrm{~mm}$, and the contracted diameters were $d=150,200$, and $250 \mathrm{~mm}$. Based on the generalized Bernoulli equation, the discharge coefficient was in the average 0.980 , with 1.00 as the coefficient for ideal flow. The total head loss from the approach flow section to the Venturi exit section amounted to some $15 \%$. Further test campaigns were directed to the velocity distribution at converging pipe exits, the efficiency of pipe diffusors, and improvements of Pitot Tubes for local velocity measurement. 
Additional projects referred mainly to industrial problems, including velocity meters, head losses across pipe bends, head losses in corrugated pipes, effect of crusted pipes on head losses, scour, surge tanks, turbine performance, mobile barrages, and fish passes. Unfortunately, even in this summary publication (Anonymous 1935), the main actors of the Beauvert Laboratory are not mentioned, so that its background remains obscure.

\section{INDIVIDUALS INVOLVED}

The individuals involved in SHF at its early era were numerous. The successful hydropower industry established around Grenoble was certainly initiated by Aristide Bergès (1833-1904), who in 1889 introduced the notion 'La Houille Blanche'. This translation from the Italian was proposed by the first Italian prime minister Camillo Benso Conte di Cavour (1810-1861) based on his relation to the first railroad tunnels across the Alps. Bergès published in 1889 a paper on the advantages of White Coal, thereby overlooking its long use in the mill industry, however. His first hydropower station at Lancey east of Grenoble produced less than $1 \%$ of the entire French energy production at the time. In contrast, he was the first overcoming considerable elevation differences with his schemes. Whereas until about 1800 , the maxima were around $10 \mathrm{~m}$ for mill wheels, Benoit Fourneyron (1802-1867) in 1836 managed in Bavaria the first record of more than $100 \mathrm{~m}$. Despite initial problems, Bergès designed in 1895 a turbine subjected by a head of $614 \mathrm{~m}$, which was increased in 1901 by the Swiss Anthelme Boucher (1856-1936) to $950 \mathrm{~m}$ at Vouvry power station. The current world record is still taken by the Swiss Dixence installation with a head of $1880 \mathrm{~m}$. However, Bergès' name is still among the leaders in this field, associated with the American Lester A. Pelton (1829-1909), whose turbine was perfectly adopted for high heads. After Bergès' death, a myth developed which was particularly important for the French Dauphiné between the two World Wars, supporting its identification with a great past in hydropower production. Another highlight for La Houille Blanche was the 1925 International Exposition of White Coal and Tourism (Fig. 1).

Jean-Baptiste Neyret (1825-1889) bought in the Romanche Valley an old industrial oven, including its water rights (Fig. 10a). From 1869 he there installed a hydraulic power scheme designed for a discharge of $10 \mathrm{~m}^{3} / \mathrm{s}$, and a head of $24 \mathrm{~m}$. This scheme was employed to produce paper from the nearby forests. In 1881, 200 workers were engaged at this first French hydraulic power site, whose power amounted to $1,800 \mathrm{~kW}$. Among the workers was also his eldest son André Neyret (1854-1931); he formed with Casimir Brenier in 1891 a society manufacturing, among other, hydraulic turbines. Brenier left the firm in 1899, however, so that Neyret took over as director, moving to Saint-Martin d'Hères, south of Grenoble. The old site was left over to Grenoble City, which there set up its Ecole Polytechnique.

The son of Neyret's brother, another Jean-Baptiste Neyret (1865-1941), together with André Neyret and Charles Beylier also were engaged in this firm, forming from 1917 to 1933 the manufacturer Neyret-Beylier-Piccard-Pictet, Grenoble (Fig. 10b). Its direction was left over to Maurice Gariel (1884-1960) with whom the modern turbine production around Grenoble was finalized. He was the first true hydraulic engineer involved in its power production. He obtained his engineering degree from Ecole Supérieure d'Electricité, Paris. His important 1919 Report on water
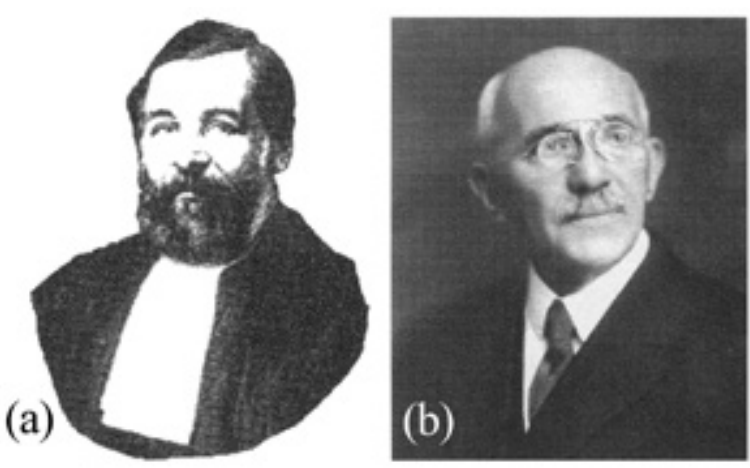

Figure 10 : (a) Jean-Baptiste Neyret, (b) his son André Neyret

hammer, co-authored by C. Camichel and D. Eydoux, for the first time compared systematic model and prototype data with the computational approach. He further published a book on hydraulic turbines (Rateau et al. 1926).

The Neyret family found in the Swiss Lucien Pictet (1864-1928) an excellent partner, forming in 1948 the turbine manufacturer Neyret-Pictet, and Neyrpic, respectively (Viollet 2005), with Gariel as its president and general director. Gariel is considered responsible for the great technical and industrial successes in the Grenoble region.

As to the Beauvert Hydraulic Laboratory, its first director was Paul Philippe Leroux, born on Jan. 10, 1889 in Paris, graduating from Ecole Naval as a naval engineer. He joined in the 1920 s the Laboratory as hydraulic engineer, taking over as its director in the late 1920s. He was in a close relation with SHF turbine furnishers, and interested in the similitude aspects of hydraulic processes. He proposed Froude modelling to deal with cavitation problems. Leroux was the victim of a car accident at Grenoble, causing his death on Sep. 04, 1933, at the age of only 44 (Hager 2009).

Rémi Henri Bourgeat was born on Nov. 01, 1874 at Grenoble, made his engineering studies at Ecole Centrale, Paris, and then was a hydraulic engineer in the Grenoble region. He joined the Beauvert Laboratory in the early 1920s acting as vice-director under Leroux. Following the latter's death, he took over as Laboratory director from 1935. Bourgeat passed away on Nov. 13, 1951 at Grenoble, at age 77. He was a member of the Technical SHF Committee from the mid-1920s; his technical interests included pipe flow, head losses, orifice and Venturi meters.

Both Leroux and Bourgeat hardly participated in congresses, except for the first ICOLD Congress in 1933 at Berlin. Both submitted no paper for the first two IAHR Congresses of which the first was also held at Berlin in 1937, whereas the second was postponed due to WWII, though with the papers published. Even at the 1949 IAHR Congress at Grenoble, Bourgeat was not present. In contrast to other French hydraulic labs, the Grenoble SHF institution was poorly represented, causing certainly its decline and its end most probably already before the German invasion to France in 1940.

\section{JOURNAL LA HOUILLE BLANCHE}

LHB, as the title of this journal is abbreviated, was initiated in 1902 as a 'General review of hydro-electric forces and their applications' (Fig. 11). It was monthly published. Initially, each issue was introduced with a one-page 
Editorial. LHB contained then some 400 pages per year in A4 format. Already in 1905 , it had dropped to 300 pages, and from the 1920 s, less than 200 pages were reached, reducing further to slightly more than 100 pages toward its end in 1938. The journal ended without obvious causes and without any announcement in early 1939, i.e. before WWII had started. The interest in matters of hydraulic engineering had become so small that nobody appears to have suffered from this change. From the current perspective this end requires for reasons, which cannot be given, however.

LHB normally consisted of numerous short contributions from hydro-electric practice, and only sporadically had longer scientific papers. It also included notes on the proceedings of the French Académie des Sciences, Paris, relating to the subject matter. Space was also taken by book reviews. From the current perspective, the many law contributions appear boring, but they were obviously important for the readers. The papers presented were not limited to hydro-electricity, but also to applications in electricity issues of power plants, in tramways, in novel train developments, in inventions in the fields studied, in projects in the French Alps, or in electric radiators. Notably, there was also interest in Swiss advances, given the wide documentation of related projects.

From today's perspective, too many papers have no authorship stated, rendering the papers anonymous. References were often poorly cited. Comparing LHB or other French engineering journals with German or Anglo-Saxon journals, large differences become obvious. The latter have then had a status familiar today, whereas the 'French standard' is by now completely outdated, because of poor readability.

In 1933, the Scientific Committee of LHB was updated. Persons as Bourgeat were eliminated for unknown reasons, and new individuals of obviously more dedication were elected, including Louis Barbillion (1871-1945), Charles Camichel (1871-1966), Georges Darrieus (1888-1979), or Etienne

QEATRIEZE ANNEE- HOS

\section{LA HOUILLE BLANCHE}

\author{
Revue générale des Forces Hydro-Electriques \\ et de leurs Applications

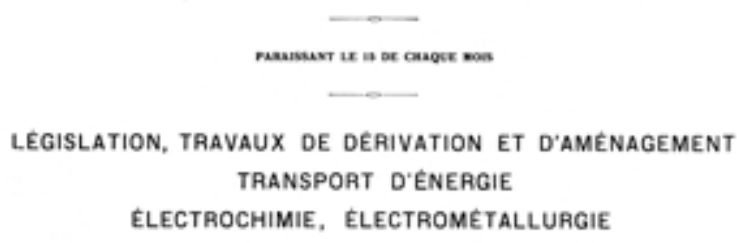

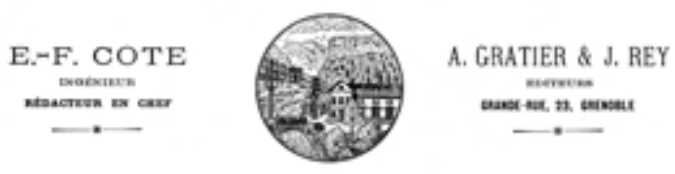

PRINCIPAUX COLLABORATEURS

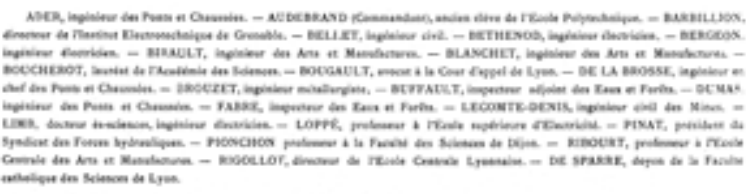

Figure 11 : Title page of $L H B$
Génissieu (1885-1950) as the most known in the hydraulic field. Note that LHB was interrupted during WWII, but then re-launched in 1945 with a completely novel impact. This is another story to be presented in a forthcoming paper.

To give an account on the then main French engineering journals dealing with hydraulics, the following are mentioned in alphabetic order:

- Annales des Ponts et Chaussées, a top international journal of the $19^{\text {th }}$ century, initiated in 1831 . It was mainly based on full and long papers of the great French hydraulic School, but finally came to the end in 1971 ;

- Le Génie Civil, dealing with all aspects of civil engineering rather as a news journal. Created in 1880, it was abandoned in 1977;

- Mémoires et Compte Rendu des Travaux de la Société des Ingénieurs Civils de France, founded in 1850 and lasting until 1965. It dealt with all aspects of civil engineering from the practical side;

- Revue Générale de l'Electricité, dealing with similar issues as LHB but with a more scientific background, initiated in 1916, lasting to 2000 ;

- Revue Générale de l'Hydraulique, one of the great hydraulics journals, dissolved in 1963 when the English-French joint Journal of Hydraulic Research of the Intl. Association of Hydraulic Research was launched;

- Sciences et Industries, founded in 1921 and lasting until 1992. It was not only active in engineering, but also in physics and natural sciences; and

- Travaux, a journal of the National French Federation of Public Works launched in 1935, dealing mainly with dam engineering.

Many more journals in this field are of course available, but the above 7 along with LHB reflect the major addition of French engineering. As noted, most of these stopped toward the end of the $20^{\text {th }}$ century, given the priority of English written contributions particularly among younger professionals. Notably, the 1945 re-launched LHB appears to be currently the only French engineering journal dealing with hydraulic engineering.

\section{CONCLUSIONS}

This work looks back to the creation of hydropower engineering mainly in the Grenoble Region, and its relation with SHF, thereby describing the three Congresses, the creation of the Hydrotechnical Society of France, and its Hydraulic Laboratory at Beauvert. Due to the two World Wars, but also due to a loss of vital interest, this Laboratory was no more operational from the 1940s. The main actors responsible for the advance of hydropower engineering in the Grenoble Region until the outbreak of WWII are also described, highlighting the history of Société Hydrotechnique de France. The development of SHF from 1945 will be considered in a joint paper.

\section{REFERENCES}

ANONYMOUs (1922) - Inauguration du Laboratoire d'Hydraulique de Beauvert à Grenoble (Inauguration of Hydraulic Laboratory of Beauvert at Grenoble). La Houille Blanche. 21, 214-219.

ANONYMOus (1924) — Le Laboratoire de Beauvert (The Laboratory of Beauvert). Recherches et Inventions. 6 (104), 56-61. 
Anonymous (1925) - La Société Hydrotechnique de France et le Laboratoire de Beauvert (The Hydrotechnical Society of France and its Laboratory at Beauvert). Proc. 3eme Congrès de la Houille Blanche Grenoble. 2, 1367-1392. Chambre Syndicale des Forces Hydrauliques : Paris.

Anonymous (1928) - Le Laboratoire d'Hydraulique de Beauvert : Son organisation, son but (The Hydraulic Laboratory of Beauvert : Its organisation, its aim). SHF : Paris.

Anonymous (1935) - Le laboratoire d'essais de la Société Hydrotechnique de France à Beauvert, près Grenoble (The Hydraulic Laboratory of SHF at Beauvert, near Grenoble). L'Energie électrique en France Science et Industrie. (11bis), 63-76.

Anonymous (1950) - List of hydraulic laboratories. Hydraulic Research. IAHR: Delft. 6.

Anonymous (1957) - Les laboratoires d'hydraulique en France (The French hydraulic laboratories). La Technique de l'Eau. 11 (4), 35-36.

Anonymous (2002) - Histoire d'industrie en Dauphiné (Industrial history of Dauphiné). Aphid: Grenoble.

BARBILlion L. (1916) - Avant-projet d'un laboratoire hydro-technique pour études des turbines et détermination de leur rendement (Draft of a hydrotechnical laboratory to study turbines and determine their efficiency). Publication Institut Electrotechnique, Grenoble. 61.

Camichel C., Eydoux D., Lhériaud J. (1914) - Mesure de débits : Le jaugeur Venturi (Discharge measurement: The Venturi meter). Proc. $2^{\text {eme }}$ Congrès de la Houille Blanche, Lyon. 2, 23-44.

Freeman J.R. (1929) - The Hydraulic Laboratory at Beauvert (near Grenoble), France. Hydraulic laboratory practice:, J.R. Freeman, ed. ASME: New York. 675-681.

HAGER W.H. (2009) - Hydraulicians in Europe. Ed. IAHR: Madrid. 2. 981.

Hahn P., HAgER W.H. (2003) - Ernest-Paul Hahn, l'EIN et la SHF (Ernest-Paul Hahn, l'EIN and the SHF). La Houille Blanche. 58(4), 103-106.

JAEGER C. (1937) - Die französischen Versuchsanstalten für Wasserbau (The French hydraulic laboratories). Wasserkraft und Wasserwirtschaft. 32(4), 44-46.
JouguET E. (1914) — Des coups de bélier : Théorie générale (Water hammer: General theory). Proc. $2^{\text {eme }}$ Congrès de la Houille Blanche, Lyon. 2, 52-119.

Leroux P. (1931) - Le laboratoire d'essais et de recherches de la SHF à Beauvert et les travaux qu'on y effectue (The SHF experimental laboratory at Beauvert and the works there made). Mémoires et Comptes Rendus des Ingénieurs Civils de France. 84 (7-8) et (9-10), 1133-1154 et 1519-1540.

Leroux P. (1932a) - The Laboratories of La Société Hydrotechnique de France. The Engineer. 154, 322-325.

Leroux P. (1932b) - L'hydraulique générale et l'hydraulique fluviale dans les laboratoires de la Société Hydrotechniques de France (General and river hydraulics at SHF laboratories). Revue Générale de l'Electricité. 31(21), 701-718.

MAURIN C. (1921) - Répertoire de laboratoires français (List of French laboratories). Recherches et Inventions. 2, 437-441; $569-575$.

NizÉRY A. (1948) - Le Laboratoire National d'Hydraulique (The National Hydraulic Laboratory). Annales des Ponts et Chaussées. 118(42), 767-849.

RateAu A. (1914) - Mesure de débits : Nouveau appareils pour la mesure et l'enregistrement des débits d'eau des installations hydrauliques (Discharge measurement: Novel apparatus for measuring and recording water discharges of hydraulic installations). Proc. $2^{\text {eme }}$ Congrès de la Houille Blanche Lyon. 2, 45-51.

Rateau A., Eydoux D., Gariel M. (1926) - Turbines hydrauliques (Hydraulic turbines). Ed. Baillière.

Routin G. (1912) - L'Annexe Diderot de l'Institut Electrotechnique de Grenoble (Diderot Annex of the Electro-technical Institute of Grenoble). Publication de l'Institut Electrotechnique : Grenoble. Publication 34.

Sparre, Le Comte De, M. (1914) - Des coups de bélier : Expériences de Verenon - coups de bélier et réservoir d'air (Water hammer: Experiences at Verenon - water hammer and air tanks). Proc. $2^{\text {eme }}$ Congrès de la Houille Blanche, Lyon. 2, $150-180$.

Viollet P.-L. (2005) - Histoire de l'énergie hydraulique (History of hydraulic energy). Presses de l'Ecole des Ponts et Chaussées: Paris. 